\title{
WEBINAR: Taliban Afghanistan, two months in
}

Edition 8, 2021

DOI: 10.37839/MAR2652-550X8.5

This panel discussion focuses on the recent Taliban take-over of Afghanistan, explores what 'Islamic' governance under the Taliban might look like and what this means for relationships with the wider region. It also looks at how this has affected issues relating to women, gender and the broader humanitarian situation.

Hear from experts in the field, Matthew Nelson (Asia Institute), Mina Zaki (cyber security professional) and Amin Saikal (University of Western Australia). With journalist Ali Moore (Ear to Asia).

Main image: Afghan women in Farah, Afghanistan. Credit: ResoluteSupportMedia/Flickr. 